\title{
Identification of Potential Extractables and Leachables in Cosmetic Plastic Packaging by Microchambers-Thermal Extraction and Pyrolysis-Gas Chromatography-Mass Spectrometry
}

\author{
Pauline Murat ${ }^{1,2}$, Sowmya Harohalli Puttaswamy ${ }^{2}$, Pierre-Jacques Ferret ${ }^{3}$, Sylvie Coslédan ${ }^{1}$ \\ and Valérie Simon $2, * \mathbb{D}$ \\ 1 Chimie analytique et Compatibilité, Pierre Fabre Dermo-Cosmétique, 17 allée Camille Soula, \\ 31320 Vigoulet-Auzil, France; pauline.murat@ensiacet.fr (P.M.); sylvie.cosledan@pierre-fabre.com (S.C.) \\ 2 Laboratoire de Chimie Agro-Industrielle (LCA), Université de Toulouse, INRA, INPT, \\ 31030 Toulouse, France; sowmyahp22@gmail.com \\ 3 Safety Assessment Department, Pierre Fabre Dermo-Cosmétique, 3 avenue Hubert Curien, \\ 31035 Toulouse Cedex, France; pierre-jacques.ferret@pierre-fabre.com \\ * Correspondence: valerie.simon@ensiacet.fr
}

Academic Editors: Mihkel Koel and Marek Tobiszewski

Received: 8 April 2020; Accepted: 25 April 2020; Published: 30 April 2020

\begin{abstract}
Most container-content interaction studies are carried out through migration tests on end products or simulants involving generally toxic solvents. This study was conducted with the aim of identifying potential leachables from materials used in cosmetic plastic packaging by using two approaches based on solvent-free extraction, i.e., solid-phase microextraction sampling and pyrolyzer/thermal desorption coupled with gas chromatography mass spectrometry. Volatile and semi-volatile intentionally and non-intentionally added substances were detected in seven packaging samples made of polypropylene, polyethylene, and styrene-acrylonitrile copolymer. Thirty-five compounds related to the polymers industry or packaging industry were identified, among them phthalates, alkanes, styrene, and cyanide derivates including degradation products, impurities, additives, plasticizers, and monomers. All except eight belong to the Cramer class I. These thermodesorption techniques are complementary to those used for migration tests.
\end{abstract}

Keywords: volatile and semi-volatile compounds; migration; plastic packaging; emission; thermal extraction; green analytical chemistry

\section{Introduction}

Plastic materials are widely used in the packaging industry, particularly in the food, pharmaceutical, medical, and cosmetic fields. The polymers most frequently used for these applications are made of polypropylene (PP), polyethylene (PE), polyvinyl chloride (PVC), polyamide (PA), polyethylene terephthalate (PET), and ethylene vinyl alcohol (EVOH). Packaging must first contain the product and provide physical protection against external aggressions (light, microbiological contamination, oxidation, etc.). It also has to provide information on the product, such as brand, instruction, and ingredients. Most of the time, plastics used for packaging contain additives to give them specific properties such as improved softness, flexibility, or resistance [1-3]. Additives can be, among others, plasticizers, ultraviolet (UV) absorbers, antioxidants, dyes, or lubricants [4,5]. Because they are not bound to the polymer matrix, these additives can migrate from the container to the content $[6,7]$, resulting in consumer exposure to chemicals that may potentially be a risk for human health. 
These molecules are called extractables or leachables, i.e., molecules that can migrate from the container to the content in extreme or normal conditions. Leaching can be migration of additives but also of non-intentionally added substances, also called NIAS [8,9]. NIAS can be impurities, degradation products, or environmental contaminants $[5,10]$. Leaching phenomenon can be controlled through evaluations called container-content interaction (CCI) studies. These studies are carried out to monitor extractables and leachables and represent important challenges for industries.

Trace levels of extractables and leachables in matrices, sometimes relatively complex, is a real challenge for analysts, because the tests need to reach very low limits (ppb levels) of detection and/or quantification. Therefore, gas chromatography-mass spectrometry (GC-MS) is often used in CCI studies, for its sensitivity, in food [6,11-15], pharmaceutical [16-19], medical [20,21], and cosmetic [7,22-25] studies. Liquid chromatography is also used, whether it is with a UV, fluorescent, [17,26-28] or mass spectrometer detector [28-32].

Such studies can be performed with migration tests on end products [22,31] and/or simulants [20,33-36] that have been in contact with the packaging material. Simulants are simple matrices used to mimic an end product. For food products, the use of simulants is ruled by the regulation $n^{\circ} 10 / 2011$ on plastic materials and articles intended to come into contact with food. In this context, six simulants are listed: $10 \%, 20 \%$, and $50 \%$ ethanol, 3\% acetic acid, vegetable oil, and poly(2,6-diphenyl-p-phenylene oxide) [37]. For cosmetic products, similar simulants, such as ethanol or glycerin, were used by Murat et al. [35,36]. Despite the simplicity of these matrices, they require sample preparation, sometimes fastidiously, and can generate interference in the detection of compounds.

To overcome these problems, CCI studies can/could also be performed on the packaging material itself. The concentration of the unknown migrants could then be much higher, and this could facilitate the identification process. Indeed, thermal extraction combined with pyrolysis (Pyr) or with thermal desorption (TD) associated to GC-MS analysis proved to be a powerful tool to investigate the composition of volatile and semi-volatile compounds. Analytical pyrolysis is mainly used to study the thermal decomposition of synthetic or natural polymers [38,39]. It produces significant amounts of components by cracking and by rearranging fragments depending on the experimental parameters. Thermal desorption is a technique mostly used for air quality studies by extracting volatile compounds sampled on a sorbent prior to GC analysis [40,41], but is also used for the study of volatile organic compounds (VOC) emissions by materials either by inserting them into cartridges [42] or into microchambers $(\mu \mathrm{CTE})$ [43].

In this context, the aim of this study was to investigate a new approach based on thermal extraction to identify potential leachables from materials used in cosmetic packaging. Two approaches based on solid-phase microextraction (SPME) sampling in microchambers and pyrolysis, both followed by GC-MS analysis are proposed to detect volatile and semi-volatile, intentionally and non-intentionally added substances in cosmetic packaging. Results are compared with those obtained by previous migration studies.

\section{Results}

\subsection{Identification of Released Compounds}

Differences were observed on the obtained chromatograms between the materials, but also between the extraction techniques (Figures 1 and 2). For the SPME- $\mu$ CTE-GC-MS study, chromatograms obtained at $110{ }^{\circ} \mathrm{C}$ vs. at $80^{\circ} \mathrm{C}$ showed more intense peaks and were used for the qualitative study. For sample $\mathrm{P} 4$, the more abundant peaks were asymmetrical, which modifies the retention time and can also hide other nearby less intense peaks. To overcome this problem, $80^{\circ} \mathrm{C}$ chromatograms were also studied. 
(a)

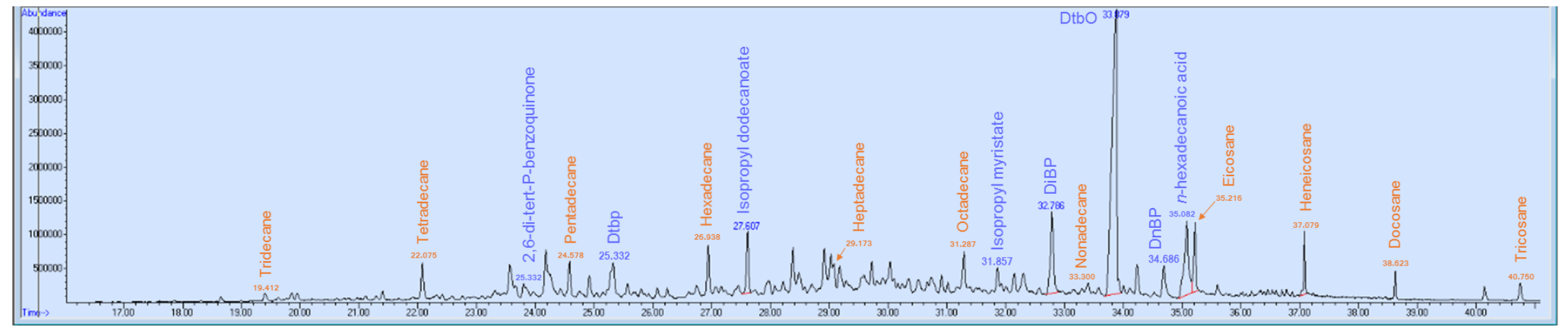

(b)

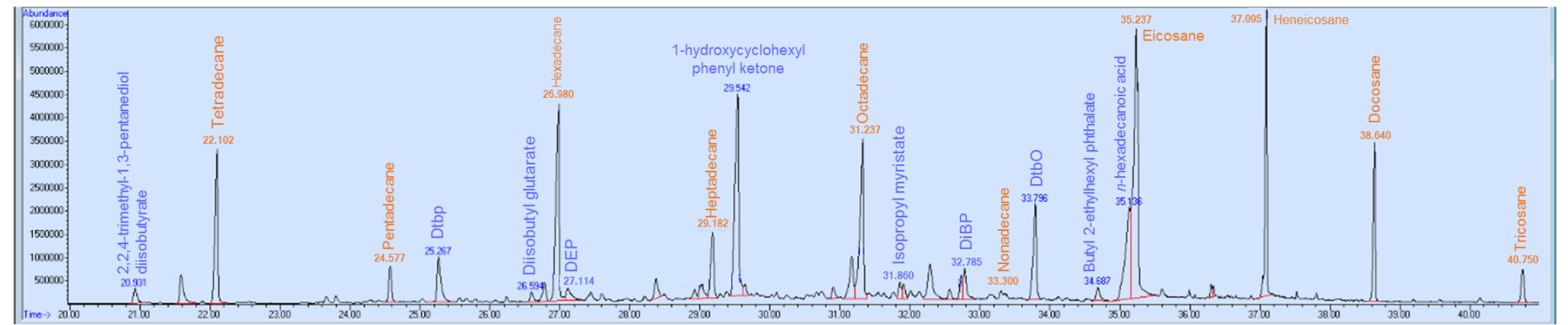

Figure 1. Chromatograms obtained using SPME sampling (PDMS) $\left(\mathrm{T}=110{ }^{\circ} \mathrm{C}\right.$, $\left.\mathrm{t}_{\text {adsorption }}=30 \mathrm{~min}\right)$ for $(\mathbf{a})$ packaging $\mathrm{P} 2(100 \%$ polypropylene $(\mathrm{PP}))$ and $(\mathbf{b})$ packaging P6 (coextruded (COEX) 70\% linear low density polyethylene (LLDPE)/30\% cross-linked low density polyethylene (XLDPE)/ethyl vinyl alcohol (EVOH)). 
(a)

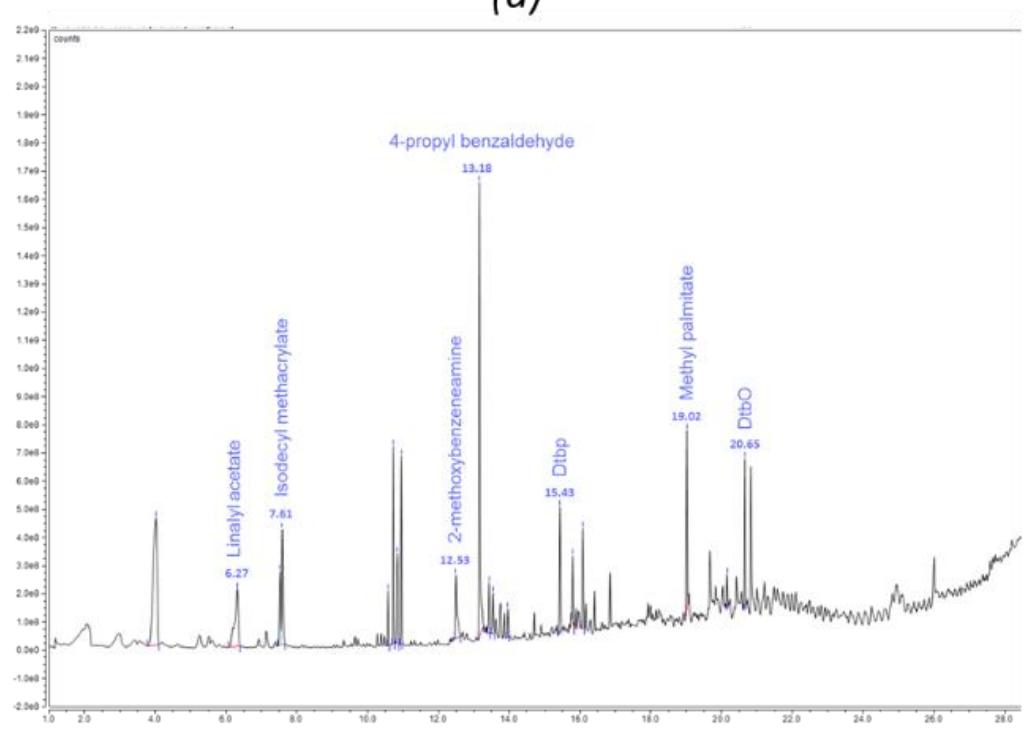

(b)

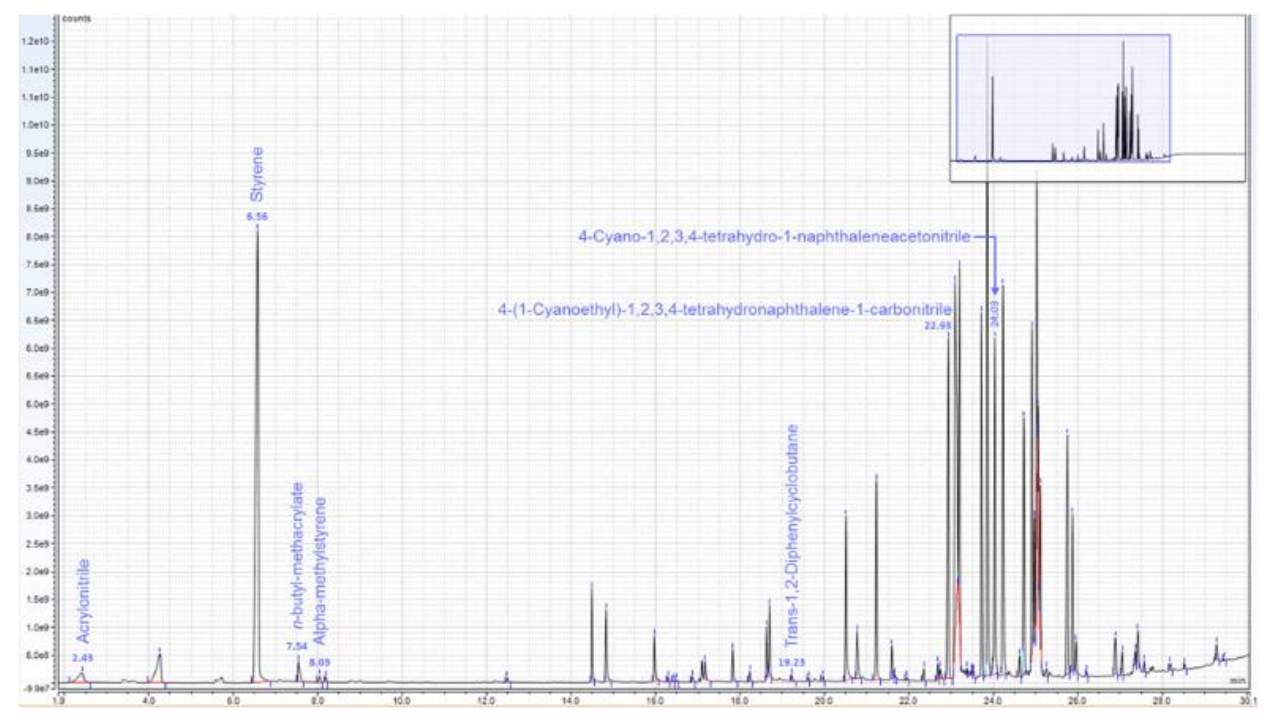

Figure 2. Chromatograms obtained by Pyr-GC-MS for (a) packaging P2 (100\% PP) and (b) packaging P3 (100\% styrene-acrylonitrile copolymer (SAN)). 
An average of 16 identified peaks for pyrolysis and 31 identified peaks for $\mu \mathrm{CTE}$ were identified. Since plastic materials are made up of petroleum products, several peaks were identified as alkanes (Figure 3). Except for P3, more peaks were identified with $\mu$ CTE than with pyrolysis. This can be explained by the fact that P3 $\mu$ CTE was realized by bulk emission, while in contrast, the other samples were analyzed by surface emission.

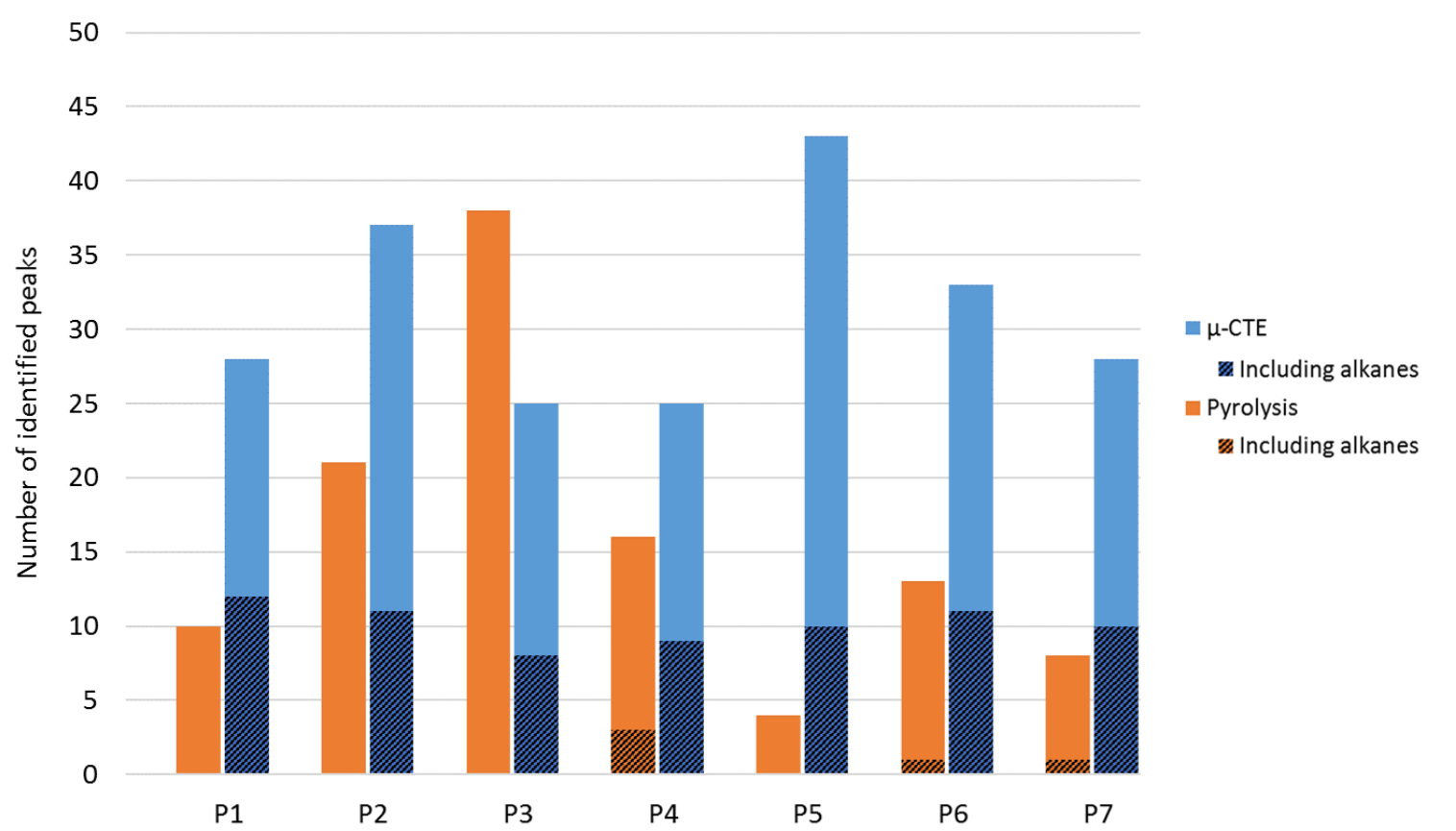

Figure 3. Number of peaks identified in every sample by Pyr (orange) and SPME- $\mu$ CTE (blue), including alkanes (striped).

Identified compounds that were related to the polymers industry or packaging industry are listed in Table 1. Only two compounds were detected both with $\mu \mathrm{CTE}$ and pyrolysis: 2,4-di-tert-burylphenol (Dtbp) and 7,9-di-tert-butyl-1-oxaspiro(4,5)deca-6,9-diene-2,8-dione (Dtbo). Moreover, they were detected in almost all the samples analyzed, except Dtbp in P3, which was presented in Groh et al. as one of the known plastic packaging-associated chemicals along with its hazards [44]. Dtbp was also detected as an extractable or leachable in several studies: Jenke et al. found it to be an extractable associated with PP, polyethylene, and polyolefin materials [45], Burman et al. found it in PP films containing Irganox 1010 and Irgafos 168 [46], and Alin et al. [47] found it in PP food packaging. Moreover, it has also been detected in PET and high density PE (HDPE) materials [48,49]. DtbO was also found in PP food packaging [47] and in pouches in PE (internal side) and PET (external side) [50]. In 2011, Löschner proposed a mechanism of degradation of additive Irgafos 168 in Dtbp and of Irganox 1010 in DtbO [51]. Acrylonitrile and styrene were both found by pyrolysis in P3 and can be considered as residual monomers. In the same material, two compounds (4-Cyano-1,2,3,4-tetrahydro-1-naphthaleneacetonitrile and 4-(1-Cyanoethyl)-1,2,3,4-tetrahydronaphthalene-1-carbonitrile) were also detected and are described by Richardson et al. as industrial process undesired by-products [52]. 
Table 1. NIST ${ }^{\circledR}$ identification of compounds extracted by Pyr and $\mu$ CTE.

\begin{tabular}{|c|c|c|c|c|c|c|c|c|c|c|c|}
\hline Compound & Molecular Formula & CAS\# & $\begin{array}{c}\text { Function } \\
\end{array}$ & Cramer Class & P1 & $\mathbf{P 2}$ & P3 & P4 & P5 & P6 & P7 \\
\hline Acrylonitrile & $\mathrm{C}_{3} \mathrm{H}_{3} \mathrm{~N}$ & 107-13-1 & $\begin{array}{l}\text { Intermediate in the synthesis of antioxidants and dyes, monomer } \\
{[53,54]}\end{array}$ & III & & & Pyr & & & & \\
\hline 2-methoxy-benzeneamine & $\mathrm{C}_{7} \mathrm{H}_{9} \mathrm{NO}$ & $90-04-0$ & Used for dyes manufacturing, printing ink [55] & III & & Pyr & & & & & \\
\hline Styrene & $\mathrm{C}_{8} \mathrm{H}_{8}$ & $100-42-5$ & Monomer, intermediate $[54,56]$ & $\mathrm{I}$ & & & Pyr & & & & \\
\hline$n$-butyl-methacrylate & $\mathrm{C}_{8} \mathrm{H}_{14} \mathrm{O}_{2}$ & $97-88-1$ & Monomer, additive [54] & $\mathrm{I}$ & & & Pyr & & & & \\
\hline Alpha-methylstyrene & $\mathrm{C}_{9} \mathrm{H}_{10}$ & $98-83-9$ & Monomer, additive [54] & I & & & Pyr & & & & \\
\hline Diethyl phthalate (DEP) & $\mathrm{C}_{12} \mathrm{H}_{14} \mathrm{O}_{4}$ & $84-66-2$ & $\begin{array}{l}\text { Solvent, plasticizer, extractable associated with polyethylene and } \\
\text { PET [45,58] }\end{array}$ & I & & & TD & TD & TD & TD & \\
\hline Linalyl acetate & $\mathrm{C}_{12} \mathrm{H}_{20} \mathrm{O}_{2}$ & $115-95-7$ & Used for plastics manufacturing, lubricant, and additives [59] & $\mathrm{I}$ & & Pyr & & & & & \\
\hline 1-dodecanol & $\mathrm{C}_{12} \mathrm{H}_{26} \mathrm{O}$ & $112-53-8$ & Plasticizer, lubricant [59] & I & & & & & TD & & \\
\hline 1-Hydroxycyclohexyl phenyl ketone & $\mathrm{C}_{13} \mathrm{H}_{16} \mathrm{O}_{2}$ & $947-19-3$ & Photo-initiator [58] & $\mathrm{I}$ & & & TD & TD & TD & TD & TD \\
\hline Disobutyl glutarate & $\mathrm{C}_{13} \mathrm{H}_{24} \mathrm{O}_{4}$ & 71195-64-7 & Plasticizer [60] & $\mathrm{I}$ & & & & & & TD & \\
\hline $\begin{array}{l}\text { 4-(1-Cyanoethyl)-1,2,3,4-tetrahydronaphthalene- } \\
\text { 1-carbonitrile }\end{array}$ & $\mathrm{C}_{14} \mathrm{H}_{14} \mathrm{~N}_{2}$ & 57964-39-3 & By-product of SAN production process [52] & III & & & PyrTD & & & & \\
\hline 4-Cyano-1,2,3,4-tetrahydro-1-naphthaleneacetonitrile & $\mathrm{C}_{14} \mathrm{H}_{14} \mathrm{~N}_{2}$ & $57964-40-6$ & By-product of SAN production process [52] & III & & & PyrTD & & & & \\
\hline 2,6-di-tert-butyl-P-benzoquinone & $\mathrm{C}_{14} \mathrm{H}_{20} \mathrm{O}_{2}$ & $719-22-2$ & $\begin{array}{l}\text { Degradation product, extractable associated with polyethylene } \\
\text { materials }[45,61]\end{array}$ & III & & TD & & & & & \\
\hline 2,4-di-tert-butylphenol (Dtbp) & $\mathrm{C}_{14} \mathrm{H}_{22} \mathrm{O}$ & $96-76-4$ & UV stabilizer, antioxidant, degradation product $[58,61]$ & $\mathrm{I}$ & Pyr & PyrTD & & PyrTD & PyrTD & PyrTD & PyrTD \\
\hline Isodecyl methacrylate & $\mathrm{C}_{14} \mathrm{H}_{26} \mathrm{O}_{2}$ & $29964-84-9$ & Monomer [54] & II & & Pyr & & & & & \\
\hline 1-tetradecene & $\mathrm{C}_{14} \mathrm{H}_{28}$ & $1120-36-1$ & Monomer, additive [54] & $\mathrm{I}$ & & & & & & & TD \\
\hline 2-ethylhexyl benzoate & $\mathrm{C}_{15} \mathrm{H}_{22} \mathrm{O}_{2}$ & $5444-75-7$ & Plasticizer [62] & $\mathrm{I}$ & & & & & TD & & \\
\hline Isopropyl dodecanoate & $\mathrm{C}_{15} \mathrm{H}_{30} \mathrm{O}_{2}$ & 10233-13-3 & Additive [54] & $\mathrm{I}$ & & TD & & TD & TD & & TD \\
\hline Trans-1,2-Diphenylcyclobutane & $\mathrm{C}_{16} \mathrm{H}_{16}$ & $20071-09-4$ & Extractable associated with polystyrene materials $[45]$ & III & & & Pyr & & & & \\
\hline Di-n-butyl phthalate (DnBP) & $\mathrm{C}_{16} \mathrm{H}_{22} \mathrm{O}_{4}$ & $84-74-2$ & $\begin{array}{l}\text { Plasticizer, catalyst, extractable associated with polyethylene, } \mathrm{PET} \text {, } \\
\text { and polystyrene materials }[45,56,58]\end{array}$ & I & & TD & & & & & TD \\
\hline Diisobutyl phthalate (DiBP) & $\mathrm{C}_{16} \mathrm{H}_{22} \mathrm{O}_{4}$ & $84-69-5$ & $\begin{array}{l}\text { Plasticizer, present in printing ink, extractable associated with } \\
\text { polyethylene materials }[45,58,61]\end{array}$ & I & & TD & & & TD & TD & \\
\hline 2,2,4-trimethyl-1,3-pentanediol diisobutyrate & $\mathrm{C}_{16} \mathrm{H}_{30} \mathrm{O}_{4}$ & $6846-50-0$ & Plasticizer, monomer [54,58] & $\mathrm{I}$ & & & & & $\mathrm{TD}$ & $\mathrm{TD}$ & TD \\
\hline 1-decanol-2 hexyl & $\mathrm{C}_{16} \mathrm{H}_{34} \mathrm{O}$ & $2425-77-6$ & Additive [54] & $\mathrm{I}$ & TD & & & & & & \\
\hline 1-hexadecanol & $\mathrm{C}_{16} \mathrm{H}_{34} \mathrm{O}$ & $36653-82-4$ & Monomer, additive [54] & $\mathrm{I}$ & & & & & & & TD \\
\hline $\begin{array}{l}\text { 7,9-di-tert-butyl-1-oxaspiro(4,5)deca-6,9-diene-2,8-dione } \\
\text { (DtbO) }\end{array}$ & $\mathrm{C}_{17} \mathrm{H}_{24} \mathrm{O}_{3}$ & $82304-66-3$ & Degradation product, impurity of Irganox $1076[58,61]$ & III & PyrTD & PyrTD & TD & PyrTD & TD & TD & TD \\
\hline Isopropyl myristate & $\mathrm{C}_{17} \mathrm{H}_{34} \mathrm{O}_{2}$ & $\begin{array}{lll}110-27-0 \\
112-390\end{array}$ & & I & & TD & & TD & $\mathrm{TD}$ & TD & \\
\hline Methyl palmitate & $\mathrm{C}_{17} \mathrm{H}_{34} \mathrm{O}_{2}$ & $112-39-0$ & Intermediate for resins and defoamer in food contact coatings [61] & $\mathrm{I}$ & & Pyr & & & & & \\
\hline 1-octadecanol & $\mathrm{C}_{18} \mathrm{H}_{38} \mathrm{O}$ & 112 & Ink solvent, plasticizer [61] & $\mathrm{I}$ & & & $\mathrm{TD}$ & & & & \\
\hline Butyl 2-ethylhexyl phthalate & $\mathrm{C}_{20} \mathrm{H}_{30} \mathrm{O}_{4}$ & $85-69-8$ & Plasticizer [63] & $\mathrm{I}$ & & & & & & TD & \\
\hline Butyl octyl phthalate & $\mathrm{C}_{20} \mathrm{H}_{30} \mathrm{O}_{4}$ & $84-78-6$ & Plasticizer [63] & $\mathrm{I}$ & & & & & TD & & \\
\hline Bis(2-ethylhexyl) adipate & $\mathrm{C}_{22} \mathrm{H}_{42} \mathrm{O}_{4}$ & 103-23-1 & Plasticizer, extractable associated with PET [45,61] & $\mathrm{I}$ & & & TD & & & & \\
\hline Bis(2-ethylhexyl) phthalate (DEHP) & $\mathrm{C}_{24} \mathrm{H}_{38} \mathrm{O}_{4}$ & $117-81-7$ & $\begin{array}{l}\text { Plasticizer, extractable associated with PET and polystyrene } \\
\text { materials }[45,58]\end{array}$ & I & & & TD & & & & \\
\hline Diisooctyl phthalate & $\mathrm{C}_{24} \mathrm{H}_{38} \mathrm{O}_{4}$ & $27554-26-3$ & Plasticizer [64] & $\mathrm{I}$ & TD & & & & & & \\
\hline
\end{tabular}


Among the 35 compounds listed, 14 are considered as plasticizers and 8 of these plasticizers are phthalates. Molar masses of the detected molecules were included between 53 (acrylonitrile) and $391 \mathrm{~g} / \mathrm{mol}$ (diisooctyl phthalate and bis(2-ethylhexyl) phthalate). Furthermore, boiling points varied from $77{ }^{\circ} \mathrm{C}$ (acrylonitrile) to around $425{ }^{\circ} \mathrm{C}$ (DtbO and 4-(1-Cyanoethyl)1,2,3,4-tetrahydronaphthalene-1-carbonitrile).

\subsection{Comparison with Simulants Study}

A migration study using aqueous and ethanolic simulants on the same packaging was realized by Murat et al. in 2019 [35]. Ten phthalates were part of the targeted compounds. Comparing results, it appears that DnBP, DEHP, DEP, and DiBP of the $\mu \mathrm{CTE}$ study were also detected in simulants of the same packaging in the migration study. In this previous work, these four compounds were detected in all the packaging samples studied here, except DEHP in P6. Measured concentrations varied from $12.4 \mu \mathrm{g} / \mathrm{L}$ for DiBP in P1 to 491.0 for DiBP in P3, both in simulant ethanol 96\%. This illustrates the fact that plastic additives (intentionally or non-intentionally added) can migrate from the material into the product.

However, with $\mu \mathrm{CTE}$, these four compounds were not detected in all the packaging, compared to the simulant study. Moreover, some phthalates found in the migration study such as benzylbutyl phthalate or diisopentyl phthalate were not detected with the pyrolysis or with the $\mu$ CTE methods. This can be explained by the fact that phthalates are semi-volatile compounds and they are present in the materials at a trace level. The liquid simulants seemed to present a higher power of extraction than did heat under the conditions of the studies.

A second study on simulants was led by Murat et al. in 2020 [36]. For this work, glycerin and liquid paraffin were used to mimic cosmetic products. The same phthalates were targeted. Once again, DEP, DiBP, DnBP, and DEHP were detected in the simulants in several packaging. Higher concentrations of DEP were measured in glycerin and liquid paraffin both in contact with P5. Only one phthalate detected in glycerin was not detected using $\mu$ CTE: diisopentyl phthalate in P7.

Comparing migration and extraction studies, it appears that they are complementary. Thermal extractions allow for the identification of numerous potential leachables, without using any solvent, during migration studies. There are limitations to both approaches. To detect all the leachables during migration studies, several chromatographic techniques must be used. Thermal extractions can highlight the presence of numerous compounds, but their capacities to migrate into simulants or products must be verified.

Eventually, thermal extractions can be used to list the additives, NIAS, and all potential leachables present in a material. Then, the migration approach can be used to check which compounds are able to migrate.

\subsection{Toxicological Aspects}

The Cramer class of the compounds presented in the Table 1 were determined using the Toxtree online tool. Cramer class I corresponds to substances with a simple structure and low toxicity. The threshold of toxicological concern for these substances is $1800 \mu \mathrm{g} /$ person/day. Cramer class II compounds are of medium toxicity and their structures are less inoffensive than structures of class I compounds. Their threshold is $540 \mu \mathrm{g} /$ person/day. Finally, Cramer class III compounds have reactive functional groups and they present a high toxicity. Their threshold is fixed at $90 \mu \mathrm{g} / \mathrm{person} / \mathrm{day}$.

Among the 35 compounds, 27 belong to class I, 1 to class II, and 7 to class III. These last ones are presented in Figure 4. Compounds detected in this work are present in the packaging materials but their ability to migrate into products such as cosmetic formulas were not tested. It would be interesting to perform simulants studies on them, as presented by Murat et al. for phthalates [24]. GC-MS methods could be developed to qualify and quantitate the compounds presented in Figure 5. Priority compounds are ones of the Cramer class III (in bold in the cartography). Finally, with quantitation 
methods, safety evaluations could be done to ensure that associations the between packaging and products are safe for the consumers.

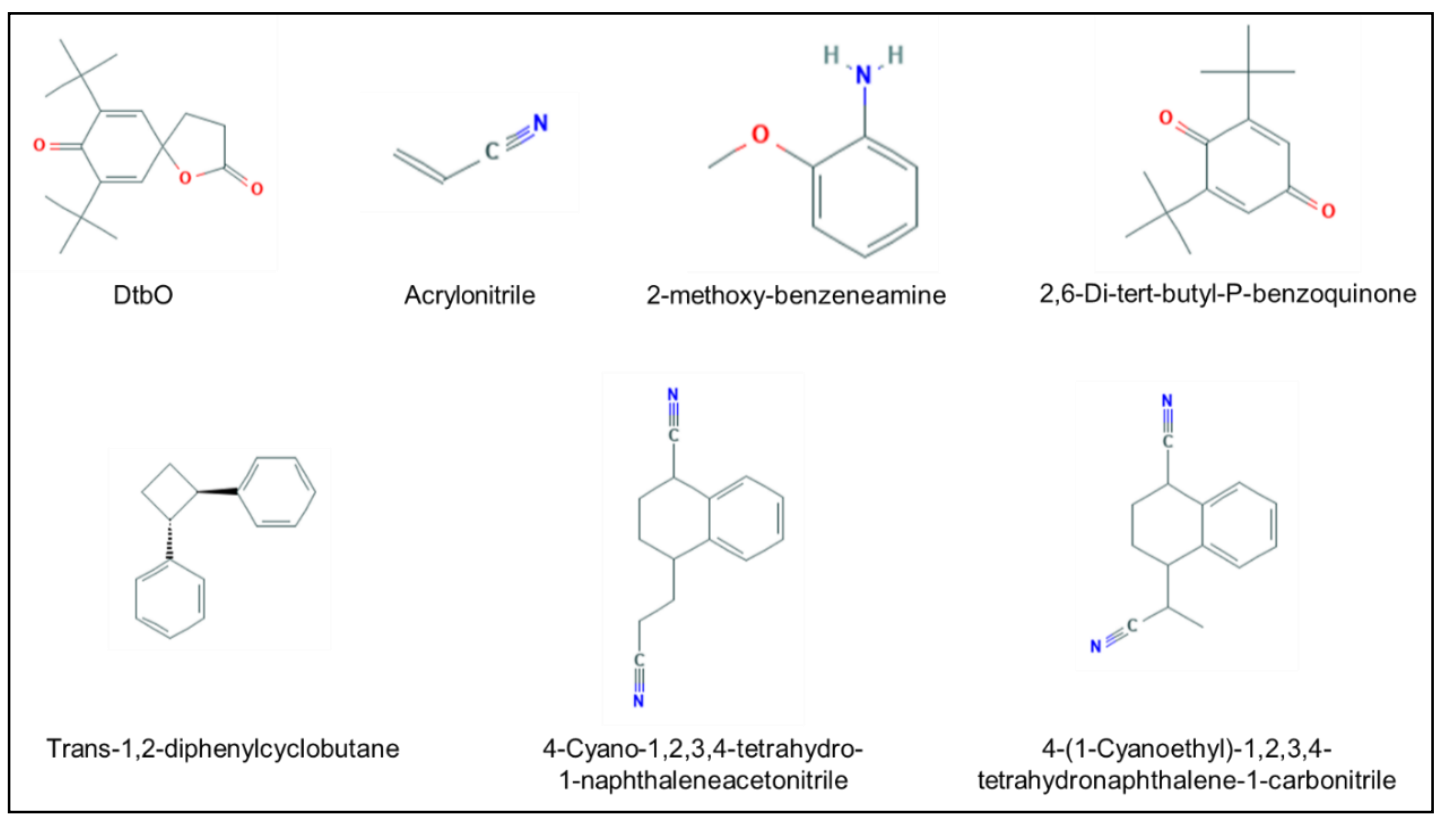

Figure 4. Structures of the detected compounds belonging to the Cramer class III.

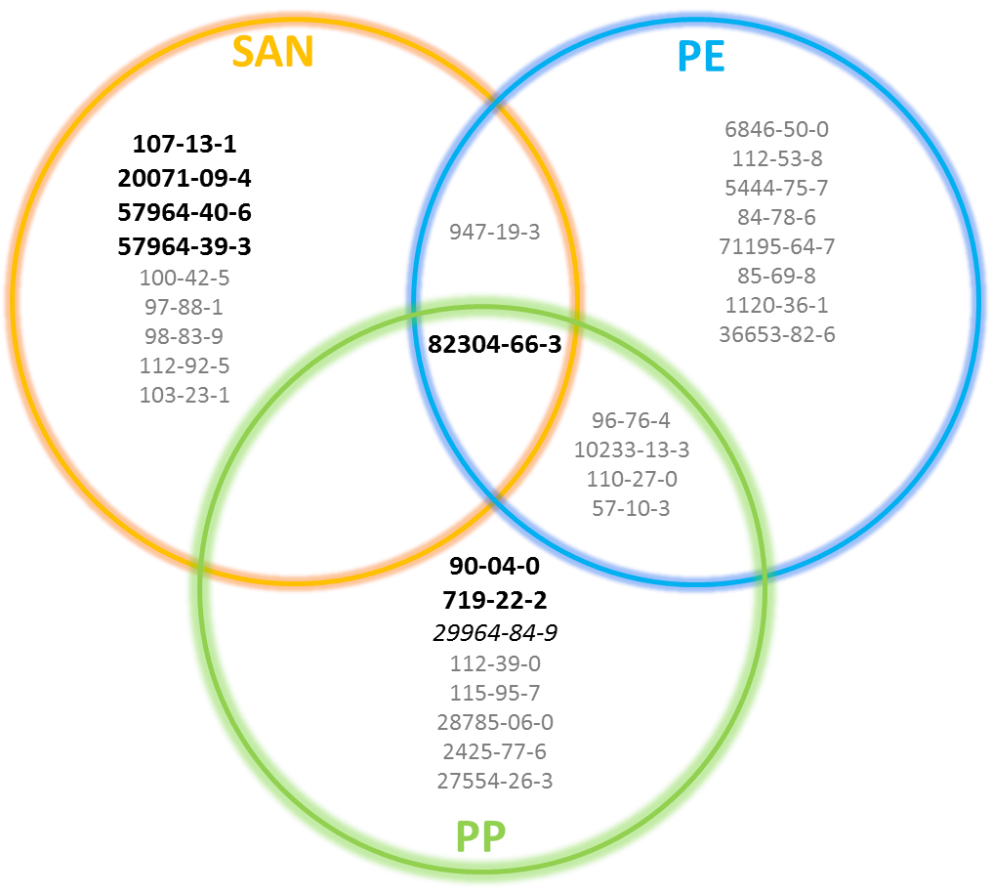

Figure 5. Cartography of the identified compounds to study by packaging materials. Cramer class III compounds are in black and bold, Cramer class II compounds in black and italic, and Cramer class I compounds in grey.

\section{Materials and Methods}

\subsection{Samples}

Seven packaging options used for cosmetic products were studied. They were all made up of thermoplastics. Two were of polypropylene but from different suppliers in order to evaluate the 
supplier influence on the leachable profile of packaging. One was of styrene-acrylonitrile copolymer (SAN) and the others were of polyethylene (high density polyethylene (HDPE), linear low density polyethylene (LLDPE), and cross-linked low density polyethylene (XLDPE)). The coextruded (COEX) studied packaging also contained ethyl vinyl alcohol (EVOH). They are described in Table 2.

Table 2. Studied packaging descriptions.

\begin{tabular}{llll}
\hline Code & Material & Appearance & Shape and Type \\
\hline P1 & $100 \%$ PP & Opaque, white & Elliptical bottle \\
P2 & $100 \%$ PP & Opaque, green & Cylindrical bottle \\
P3 & $100 \%$ SAN & Opaque, white & Cylindrical bottle \\
P4 & $100 \%$ HDPE & Opaque, white & Cylindrical bottle \\
P5 & $70 \%$ LLDPE/30\% XLDPE & Opaque, white & Cylindrical tube \\
P6 & COEX 70\% LLDPE/30\% & Opaque, white & Cylindrical tube \\
P7 & XLDPE//EVOH & Opaque, white & Cylindrical tube \\
\hline
\end{tabular}

\subsection{Samples Preparation}

Packaging samples were cut using clean scissors or when necessary (for P3) a Dremel model 300 (Dremel Europe, Breda, NL) for pyrolysis analyses. Approximately 1-2 $\mu \mathrm{g}$ of material were inserted into a quartz tube for Pyr-GC-MS analysis. Surface emission testing was applied to all the packaging except $\mathrm{P} 3$ for $\mu \mathrm{CTE}$ extraction. To do so, $6.4 \mathrm{~cm}$ diameter circular samples were cut from the packaging samples and put on spacers for microchambers. P3 was analyzed by bulk emission testing (around $1 \mathrm{~g}$ ). All tests were duplicated.

\subsection{Instrumentation and Conditions}

A Micro-Chamber/Thermal Extractor ( $\mu \mathrm{CTE}$ ) 250-series (Markes International, Llantrisant, UK) with four micro-chambers ( $36 \mathrm{~mm}$ deep, $64 \mathrm{~mm}$ in diameter) was used to heat samples at $80^{\circ} \mathrm{C}$ and $110^{\circ} \mathrm{C}$. Emissions were extracted by SPME. A preliminary study was completed concerning material P5 and involving four types of fibers (Supelco, Bellefonte, PA, USA): polydimethylsiloxane (PDMS) $100 \mu \mathrm{m}$, carboxen/PDMS $75 \mu \mathrm{m}$, divinylbenzene/carboxen/PDMS fiber 50/30 $\mu \mathrm{m}$, and polyacrylate $85 \mu \mathrm{m}$. The chromatographic patterns obtained for the first three fibers are quite similar due to the observed retention times and peak intensity. In contrast, for the polyacrylate fiber, the chromatogram has not only fewer peaks and but also lower intensity. The PDMS fiber makes it possible to detect peaks characterized by a greater retention time amplitude. It was thus chosen for the study. After sample collection, SPME fiber was desorbed for $5 \mathrm{~min}$ and analyzed by an Agilent 6890 gas chromatograph coupled with a 5973 Network mass spectrometer. Injection was in splitless mode on a DB5-MS (30 m $\times$ $0.25 \mathrm{~mm} \times 0.25 \mu \mathrm{m}$ ) column from Agilent (Les Ulis, France). Helium was used as carrier gas with a flow rate of $1.3 \mathrm{~mL} / \mathrm{min}$. The oven temperature was programmed from $50{ }^{\circ} \mathrm{C}$ (held $5 \mathrm{~min}$ ) to $200^{\circ} \mathrm{C}$ at $5{ }^{\circ} \mathrm{C} / \mathrm{min}$ and then to $250{ }^{\circ} \mathrm{C}$ at $30^{\circ} \mathrm{C} / \mathrm{min}$ (held $7 \mathrm{~min}$ ). Temperatures of the injector, quadrupole, and ion source were $250^{\circ} \mathrm{C}, 150^{\circ} \mathrm{C}$, and $230^{\circ} \mathrm{C}$, respectively. The MS detector was run in electron impact mode with electron energy of $70 \mathrm{eV}$. Data acquisition was made in SCAN mode from 35 to $500 \mathrm{amu}$. The analytical system was controlled by MSD Chemstation software (Agilent, Les Ulis, France) and comprised a library of mass spectra (NIST ${ }^{\circledR}$ Version 2.2).

A CDS 6150 pyrolyzer (Oxford, PA, USA) was used for pyrolysis analyses. Samples were heated at $340{ }^{\circ} \mathrm{C}$ for $30 \mathrm{~s}$ and the transfer line temperature was $280^{\circ} \mathrm{C}$. The analytical system consisted of a Thermo Scientific Trace 1310 gas chromatograph coupled with a TSQ 9000 mass detector (San José, CA, USA). A ZB-50 capillary column ( $30 \mathrm{~m}$ length, $0.25 \mathrm{~mm}, 0.25 \mu \mathrm{m}$ film thickness) was used for separation (Phenomenex, Torrance, CA, USA). Carrier gas was helium at $1.3 \mathrm{~mL} / \mathrm{min}$. Injection was in split mode with a ratio of 70:1 to avoid the detector contamination with polymers fragments. The temperature gradient began at $40{ }^{\circ} \mathrm{C}$ for $1 \mathrm{~min}$ and was then raised to $320^{\circ} \mathrm{C}$ at $10^{\circ} \mathrm{C} / \mathrm{min}$ (held for $10 \mathrm{~min}$ ). The MS 
detector was run in electron impact mode with electron energy of $70 \mathrm{eV}$. Data acquisition was made in SCAN mode from 45 to $600 \mathrm{amu}$. The analytical system was controlled by Chromeleon ${ }^{\mathrm{TM}}$ software (Thermo Fisher Scientific, San José, CA, USA) and comprised a library spectra (NIST ${ }^{\circledR}$ Version 2.2).

\subsection{Qualitative Analysis}

For both techniques, blanks were performed to check that no eventual contamination occurred during the extraction and analytical processes (empty microchamber and empty pyrolysis tube).

Identification was carried out by using the NIST Mass spectral libraries. Only hypotheses of identification with match and reverse match factors above 700 were considered as acceptable.

\section{Conclusions}

SPME- $\mu$ CTE-GC-MS and Pyr-GC-MS methods allowed for the study of a wide spectrum of compounds without the use of solvents. The studied compounds included phthalates, styrene, and cyanide derivates along with degradation products, impurities, additives, plasticizers, and monomers. Unlike most methods used for migration studies, thermodesorption does not need toxic solvents. This solvent-free technique is compatible with the principles of Green Chemistry. It is an innovative approach to study the container-content interactions in cosmetics.

Author Contributions: Conceptualization, P.M., S.C., V.S.; methodology, P.M., V.S.; Performance of the experiments, S.H.P., P.M.; supervision, V.S.; project administration, S.C., P.-J.F.; writing-original draft preparation: P.M., V.S.; writing-review and editing: P.M., S.C., P.-J.F., V.S. All authors have read and agreed to the published version of the manuscript.

Funding: The study was funded partially by the French National Association of Research and Technology (CIFRE 2017/0159).

Acknowledgments: The authors thank Catherine Claparols of Institut de Chimie de Toulouse ICT-FR2599 (Université de Toulouse, CNRS, Toulouse, France, www.ict.ups-tlse.fr) for her valuable help with Pyr-GC-MS analysis. They also wish to acknowledge Aline Carvalho for her precious help on this work and Arthur Kisseleff for English editing.

Conflicts of Interest: The authors declare that there are no conflict of interest.

\section{References}

1. Thompson, R.C.; Moore, C.J.; Saal, F.S.V.; Swan, S. Plastics, the environment and human health: Current consensus and future trends. Philos. Trans. R. Soc. B: Biol. Sci. 2009, 364, 2153-2166. [CrossRef] [PubMed]

2. Bradley, E.; Coulier, L. An Investigation into the Reaction and Breakdown Products from Starting Substances Used to Produce Food Contact Plastics; Food Standards Agency: London, UK, 2007.

3. Cao, X.-L. Determination of phthalates and adipate in bottled water by headspace solid-phase microextraction and gas chromatography/mass spectrometry. J. Chromatogr. A 2008, 1178, 231-238. [CrossRef] [PubMed]

4. Bi, X.; Pan, X.; Yuan, S.; Wang, Q. Plasticizer Contamination in Edible Vegetable Oil in a U.S. Retail Market. J. Agric. Food Chem. 2013, 61, 9502-9509. [CrossRef] [PubMed]

5. Lau, O.-W.; Wong, S.-K. Contamination in food from packaging material. J. Chromatogr. A 2000, 882, $255-270$. [CrossRef]

6. Fasano, E.; Bono-Blay, F.; Cirillo, T.; Montuori, P.; Lacorte, S. Migration of phthalates, alkylphenols, bisphenol A and di(2-ethylhexyl)adipate from food packaging. Food Control. 2012, 27, 132-138. [CrossRef]

7. Gimeno, P.; Maggio, A.-F.; Bousquet, C.; Quoirez, A.; Civade, C.; Bonnet, P.-A. Analytical method for the identification and assay of 12 phthalates in cosmetic products: Application of the ISO 12787 international standard "Cosmetics-Analytical methods-Validation criteria for analytical results using chromatographic techniques". J. Chromatogr. A 2012, 1253, 144-153. [CrossRef]

8. Bignardi, C.; Cavazza, A.; Laganà, C.; Salvadeo, P.; Corradini, C. Release of non-intentionally added substances (NIAS) from food contact polycarbonate: Effect of ageing. Food Control. 2017, 71, 329-335. [CrossRef] 
9. Muncke, J. Endocrine disrupting chemicals and other substances of concern in food contact materials: An updated review of exposure, effect and risk assessment. J. Steroid Biochem. Mol. Biol. 2011, 127, 118-127. [CrossRef]

10. Nerín, C.; Alfaro, P.; Aznar, M.; Domeño, C. The challenge of identifying non-intentionally added substances from food packaging materials: A review. Anal. Chim. Acta 2013, 775, 14-24. [CrossRef]

11. Amiridou, D.; Voutsa, D. Alkylphenols and phthalates in bottled waters. J. Hazard. Mater. 2011, 185, $281-286$. [CrossRef]

12. Fierens, T.; Servaes, K.; Van Holderbeke, M.; Geerts, L.; De Henauw, S.; Sioen, I.; Vanermen, G. Analysis of phthalates in food products and packaging materials sold on the Belgian market. Food Chem. Toxicol. 2012, 50, 2575-2583. [CrossRef] [PubMed]

13. Cacho, J.; Campillo, N.; Viñas, P.; Hernández-Córdoba, M. Determination of alkylphenols and phthalate esters in vegetables and migration studies from their packages by means of stir bar sorptive extraction coupled to gas chromatography-mass spectrometry. J. Chromatogr. A 2012, 1241, 21-27. [CrossRef] [PubMed]

14. Casajuana, N.; Lacorte, S. New Methodology for the Determination of Phthalate Esters, Bisphenol A, Bisphenol A Diglycidyl Ether, and Nonylphenol in Commercial Whole Milk Samples. J. Agric. Food Chem. 2004, 52, 3702-3707. [CrossRef] [PubMed]

15. Guo, Y.; Zhang, Z.; Liu, L.; Li, Y.; Ren, N.; Kannan, K. Occurrence and Profiles of Phthalates in Foodstuffs from China and Their Implications for Human Exposure. J. Agric. Food Chem. 2012, 60, 6913-6919. [CrossRef]

16. Gimeno, P.; Thomas, S.; Bousquet, C.; Maggio, A.-F.; Civade, C.; Brenier, C.; Bonnet, P.-A. Identification and quantification of 14 phthalates and 5 non-phthalate plasticizers in PVC medical devices by GC-MS. J. Chromatogr. B 2014, 949, 99-108. [CrossRef]

17. Jenke, D.R.; Castner, J.; Egert, T.; Feinberg, T.; Hendricker, A.; Houston, C.; Hunt, D.G.; Lynch, M.; Shaw, A.; Nicholas, K.; et al. Extractables Characterization for Five Materials of Construction Representative of Packaging Systems Used for Parenteral and Ophthalmic Drug Products. PDA J. Pharm. Sci. Technol. 2013, 67, 448-511. [CrossRef]

18. Roberts, D.; Feilden, A.; Barlow, R.; D'Silva, K.; Silcock, P. Confident Identification of Leachable Impurities from Pharmaceutical Container Closure Materials Using Orbitrap-Mass-Spectrometer-Based GC-MS; Application Note; Thermo Scientific: Waltham, MA, USA, 2016.

19. Pan, C.; Harmon, F.; Toscano, K.; Liu, F.; Vivilecchia, R. Strategy for identification of leachables in packaged pharmaceutical liquid formulations. J. Pharm. Biomed. Anal. 2008, 46, 520-527. [CrossRef]

20. Bourdeaux, D.; Yessaad, M.; Chennell, P.; Larbre, V.; Eljezi, T.; Bernard, L.; Sautou, V. Analysis of PVC plasticizers in medical devices and infused solutions by GC-MS. J. Pharm. Biomed. Anal. 2016, 118, $206-213$. [CrossRef]

21. Thakare, V.; Mayr, B.; Artenjak, A.; Nianios, D.; Sest, M.; Müller, M.; Maltsev, O.V.; Nowicki, K.; Mischo, A.; Ehrenstrasser, C.; et al. Investigation of drug product and container-closure interactions: A case study of diluent containing prefilled syringe. Eur. J. Pharm. Biopharm. 2019, 140, 67-77. [CrossRef]

22. Thomas, C.; Siong, D.; Pirnay, S. Evaluation of the content - containing interaction in cosmetic products using gas chromatography-mass spectrometry. Int. J. Cosmet. Sci. 2014, 36, 327-335. [CrossRef]

23. Shen, H.-Y.; Jiang, H.-L.; Mao, H.-L.; Pan, G.; Zhou, L.; Cao, Y.-F. Simultaneous determination of seven phthalates and four parabens in cosmetic products using HPLC-DAD and GC-MS methods. J. Sep. Sci. 2007, 30, 48-54. [CrossRef] [PubMed]

24. Chen, H.; Wang, C.; Wang, X.; Hao, N.; Liu, J. Determination of phthalate esters in cosmetics by gas chromatography with flame ionization detection and mass spectrometric detection. Int. J. Cosmet. Sci. 2005, 27, 205-210. [CrossRef] [PubMed]

25. Guo, Y.; Kannan, K. A Survey of Phthalates and Parabens in Personal Care Products from the United States and Its Implications for Human Exposure. Environ. Sci. Technol. 2013, 47, 14442-14449. [CrossRef] [PubMed]

26. Cirillo, T.; Latini, G.; Castaldi, M.A.; DiPaola, L.; Fasano, E.; Esposito, F.; Scognamiglio, G.; Di Francesco, F.; Cobellis, L. Exposure to Di-2-Ethylhexyl Phthalate, Di-N-Butyl Phthalate and Bisphenol A through Infant Formulas. J. Agric. Food Chem. 2015, 63, 3303-3310. [CrossRef]

27. Feng, C.-H.; Jiang, S.-R. Micro-scale quantitation of ten phthalate esters in water samples and cosmetics using capillary liquid chromatography coupled to UV detection: Effective strategies to reduce the production of organic waste. Microchim. Acta 2012, 177, 167-175. [CrossRef] 
28. Viñas, P.; Campillo, N.; Pastor-Belda, M.; Oller, A.; Hernández-Córdoba, M. Determination of phthalate esters in cleaning and personal care products by dispersive liquid-liquid microextraction and liquid chromatography-tandem mass spectrometry. J. Chromatogr. A 2015, 1376, 18-25. [CrossRef]

29. Ferrer, E.; Santoni, E.; Vittori, S.; Font, G.; Mañes, J.; Sagratini, G. Simultaneous determination of bisphenol A, octylphenol, and nonylphenol by pressurised liquid extraction and liquid chromatography-tandem mass spectrometry in powdered milk and infant formulas. Food Chem. 2011, 126, 360-367. [CrossRef]

30. Lateef, S.S. Extractables and Leachables Detected in Ophthalmic Drug Products-Detection and Identification Using High-Resolution LC/MS/MS.; Agilent Technologies Inc.: Santa Clara, CA, USA, 2016.

31. Zhang, Y.; Sun, S.; Xing, X.; Du, Z.; Guo, Q.; Yu, W. Detection and Identification of Leachables in Vaccine from Plastic Packaging Materials Using UPLC-QTOF MS with Self-Built Polymer Additives Library. Anal. Chem. 2016, 88, 6749-6757. [CrossRef]

32. Pinguet, J.; Kerckhove, N.; Eljezi, T.; Lambert, C.; Moreau, E.; Bernard, L.; Boeuf, B.; Decaudin, B.; Genay, S.; Masse, M.; et al. New SPE-LC-MS/MS method for the simultaneous determination in urine of 22 metabolites of DEHP and alternative plasticizers from PVC medical devices. Talanta 2019, 198, 377-389. [CrossRef]

33. Bernard, L.; Cueff, R.; Breysse, C.; Décaudin, B.; Sautou, V. Migrability of PVC plasticizers from medical devices into a simulant of infused solutions. Int. J. Pharm. 2015, 485, 341-347. [CrossRef]

34. Ubeda, S.; Aznar, M.; Rosenmai, A.K.; Vinggaard, A.M.; Nerín, C. Migration studies and toxicity evaluation of cyclic polyesters oligomers from food packaging adhesives. Food Chem. 2020, 311, 125918. [CrossRef] [PubMed]

35. Murat, P.; Ferret, P.-J.; Coslédan, S.; Simon, V. Assessment of targeted non-intentionally added substances in cosmetics in contact with plastic packagings. Analytical and toxicological aspects. Food Chem. Toxicol. 2019, 128, 106-118. [CrossRef] [PubMed]

36. Murat, P.; Ferret, P.-J.; Coslédan, S.; Simon, V. Development of a HS-SPME-GC-MS method for the analysis of phthalates in glycerin and liquid paraffin: Application to safety evaluation of cosmetic packagings. Anal. Bioanal. Chem. 2020, 1-12. [CrossRef] [PubMed]

37. European Commission Commission Regulation (EU). $n^{\circ} 10 / 2011$ of 14 January 2011 on Plastic Materials and Articles Intended to Come into Contact with Food; European Union: Brussels, Belgium, 2011.

38. Takahashi, F.; Kobayashi, M.; Kobayashi, A.; Kobayashi, K.; Asamura, H. High-Frequency Heating Extraction Method for Sensitive Drug Analysis in Human Nails. Molecules 2018, 23, 3231. [CrossRef] [PubMed]

39. Yamamoto, Y.; Koga, N. Thermal Decomposition of Maya Blue: Extraction of Indigo Thermal Decomposition Steps from a Multistep Heterogeneous Reaction Using a Kinetic Deconvolution Analysis. Molecules 2019, 24, 2515. [CrossRef] [PubMed]

40. Martinez, T.; Bertron, A.; Escadeillas, G.; Ringot, E.; Simon, V. BTEX abatement by photocatalytic TiO2-bearing coatings applied to cement mortars. Build. Environ. 2014, 71, 186-192. [CrossRef]

41. Simon, V.; Uitterhaegen, E.; Robillard, A.; Ballas, S.; Véronèse, T.; Vilarem, G.; Merah, O.; Talou, T.; Evon, P. VOC and carbonyl compound emissions of a fiberboard resulting from a coriander biorefinery: Comparison with two commercial wood-based building materials. Environ. Sci. Pollut. Res. 2020,1-13. [CrossRef]

42. Candelier, K.; Dumarcay, S.; Pétrissans, A.; Pétrissans, M.; Kamdem, P.; Gérardin, P. Thermodesorption coupled to GC-MS to characterize volatiles formation kinetic during wood thermodegradation. J. Anal. Appl. Pyrolysis 2013, 101, 96-102. [CrossRef]

43. Nohr, M.; Horn, W.; Wiegner, K.; Richter, M.; Lorenz, W. Development of a material with reproducible emission of selected volatile organic compounds - $\mu$-Chamber study. Chemosphere 2014, 107, $224-229$. [CrossRef] [PubMed]

44. Groh, K.; Backhaus, T.; Almroth, B.C.; Geueke, B.; Inostroza, P.; Lennquist, A.; Leslie, H.A.; Maffini, M.; Slunge, D.; Trasande, L.; et al. Overview of known plastic packaging-associated chemicals and their hazards. Sci. Total Environ. 2019, 651, 3253-3268. [CrossRef] [PubMed]

45. Jenke, D. Compatibility of Pharmaceutical Products and Contact Materials: Safety Considerations Associated with Extractables and Leachables; John Wiley \& Sons Inc.: Hoboken, NJ, USA, 2009; ISBN 978-1-118-67947-0.

46. Burman, L.; Albertsson, A.-C.; Höglund, A. Solid-phase microextraction for qualitative and quantitative determination of migrated degradation products of antioxidants in an organic aqueous solution. J. Chromatogr. A 2005, 1080, 107-116. [CrossRef] [PubMed] 
47. Alin, J.; Hakkarainen, M. Microwave Heating Causes Rapid Degradation of Antioxidants in Polypropylene Packaging, Leading to Greatly Increased Specific Migration to Food Simulants As Shown by ESI-MS and GC-MS. J. Agric. Food Chem. 2011, 59, 5418-5427. [CrossRef] [PubMed]

48. Alin, J.; Hakkarainen, M. Combined Chromatographic and Mass Spectrometric Toolbox for Fingerprinting Migration from PET Tray during Microwave Heating. J. Agric. Food Chem. 2013, 61, 1405-1415. [CrossRef] [PubMed]

49. Dutra, C.; Pezo, D.; Freire, M.T.D.A.; Nerin, C.; Reyes, F. Determination of volatile organic compounds in recycled polyethylene terephthalate and high-density polyethylene by headspace solid phase microextraction gas chromatography mass spectrometry to evaluate the efficiency of recycling processes. J. Chromatogr. A 2011, 1218, 1319-1330. [CrossRef]

50. Ibarra, V.A.G.; Sendón, R.; Bustos, J.; Losada, P.P.; De Quirós, A.R.-B. Estimates of dietary exposure of Spanish population to packaging contaminants from cereal based foods contained in plastic materials. Food Chem. Toxicol. 2019, 128, 180-192. [CrossRef]

51. Löschner, D.; Rapp, T.; Schlosser, F.-U.; Schuster, R.; Stottmeister, E.; Zander, S. Experience with the application of the draft European Standard prEN 15768 to the identification of leachable organic substances from materials in contact with drinking water by GC-MS. Anal. Methods 2011, 3, 2547. [CrossRef]

52. Richardson, S.D.; Collette, T.; Price, P.C.; Genicola, F.A.; Jenks, J.W.; Thruston, A.D.; Ellington, J.J. Identification of drinking water contaminants in the course of a childhood cancer investigation in Toms River, New Jersey. J. Expo. Sci. Environ. Epidemiol. 1999, 9, 200-216. [CrossRef]

53. O'Neil, M.J. (Ed.) The Merck Index: An Encyclopedia of Chemicals, Drugs, and Biologicals, 14th ed; Merck Handbooks; Merck: Whitehouse Station, NJ, USA, 2006; ISBN 978-0-911910-00-1.

54. Biryol, D.; Nicolas, C.I.; Wambaugh, J.F.; Phillips, K.; Isaacs, K.K. High-throughput dietary exposure predictions for chemical migrants from food contact substances for use in chemical prioritization. Environ. Int. 2017, 108, 185-194. [CrossRef]

55. COWI. Danish Technological Institute Hazardous Substances in Plastic Materials; Norwegian Climate and Pollution Agency: Oslo, Norway, 2013.

56. Stenmarck, Å.; Belleza, E.L.; Fråne, A.; Busch, N.; Larsen, Å.; Wahlström, M. Hazardous Substances in Plastics:-Ways to Increase Recycling; Nordisk Ministerråd: Copenhagen, Denmark, 2017.

57. Su, Q.Z.; Vera, P.; Van de Wiele, C.; Nerín, C.; Lin, Q.B.; Zhong, H.N. Non-target screening of (semi-)volatiles in food-grade polymers by comparison of atmospheric pressure gas chromatography quadrupole time-of-flight and electron ionization mass spectrometry. Talanta 2019, 202, 285-296. [CrossRef]

58. Rajbux, C.; Pereira, J.; Selbourne, M.D.C.; Costa-Pinto, A.R.; Poças, F. Assessment of baby Bibs. GC-MS screening, migration into saliva and insight of toxicity with QSAR tools. Food Control. 2020, 109, 106951. [CrossRef]

59. United States Environmental Protection Agency CPCat: Chemical and Product Categories. Available online: https://actor.epa.gov/cpcat/faces/search.xhtml;jsessionid=6A32B2AEE39BDEF95E8F4E39E7698394 (accessed on 24 February 2020).

60. Commission Européenne CosIng. Available online: https:/ec.europa.eu/growth/tools-databases/cosing/ (accessed on 18 February 2020).

61. Ibarra, V.A.G.; De Quirós, A.R.-B.; Losada, P.P.; Sendón, R. Non-target analysis of intentionally and non intentionally added substances from plastic packaging materials and their migration into food simulants. Food Packag. Shelf Life 2019, 21, 100325. [CrossRef]

62. Wypych, A. Databook of Plasticizers; Elsevier: Scarborough, UK, 2017; ISBN 978-1-927885-15-4.

63. Flick, E.W. Plastics Design Library Plastics Additives Database 2004; William Andrew: Norwich, NY, USA, 2004.

64. Bolgar, M.; Hubball, J.; Groeger, J.; Meronek, S. (Eds.) Handbook for the Chemical Analysis of Plastic and Polymer Additives, 2nd ed.; CRC Press: Boca Raton, FL, USA, 2016; ISBN 978-1-4398-6075-5.

Sample Availability: Not Available.

(C) 2020 by the authors. Licensee MDPI, Basel, Switzerland. This article is an open access article distributed under the terms and conditions of the Creative Commons Attribution (CC BY) license (http://creativecommons.org/licenses/by/4.0/). 